
\title{
28 Research Square \\ Validation of the Palliative Competency Tool: An Instrument To Qualify Medical Education (Validation of Palliative Competency Tool)
}

Ursula Bueno do Prado Guirro ( $\nabla$ ursula@ufpr.br)

Universidade Federal do Parana https://orcid.org/0000-0003-4879-3057

Carla Corradi Perini

Pontificia Universidade Catolica do Parana

Jose Eduardo de Siqueira

Pontificia Universidade Catolica do Parana

\section{Research article}

Keywords: Curriculum Development/Evaluation, Interdisciplinary Medical Education, Medical Humanities, Professional Development, Qualities/Skills/Values/Attitudes

Posted Date: May 29th, 2020

DOI: https://doi.org/10.21203/rs.3.rs-31496/v1

License: (c) (i) This work is licensed under a Creative Commons Attribution 4.0 International License. Read Full License 


\section{Abstract}

Introduction: It is necessary to determine which competencies in Palliative Care (PC) have been acquired and which ones need to be improved. The aim was to develop and validate an instrument to assess the acquisition of competencies in PC care among medical students denominated Palliative Competency Tool (Pallicomp).

Materials and methods: It were consisted of developing statements based on the competencies as described by the European Association for Palliative Care. The content was validated by experts, respecting the Delphi methodology. The instrument was applied to a group of medical students $(n=71)$ enrolled at the final of 8 th semester and statically validated.

Results: Of the 30 questions developed, 24 were refined and approved by experts. The tool was applied to 71 medical students, only $12.7 \%$ had excellent performance and four out of ten competencies were underperformed. The statistical validation consisted of Bartlett's sphericity test, which showed adequate correlation for factor analysis $(p<0.001)$; the Kaiser-Meyer-Olkin test for sample adequacy $(0.7)$, and Conbach's alpha coefficient for the internal consistency $(a=0.7)$.

Conclusions: Can be concluded that it was possible to construct and validate Palliative Competency Tool (PalliComp), an instrument of qualification of competencies acquisition of PC.

\section{Introduction}

Knowledge of the technical content in Palliative Care (PC) is essential for health care, but it is not enough. It is necessary to articulate knowledge with practice, that is, mobilize knowledge in skills and attitudes. For good PC assistance, the World Health Organization [1] recommends that is necessary to know content related to ethics, communication and decision-making process, with respect to the values of those involved. The association of knowledge, skills and attitudes defines the term competency $[2,3]$.

The teaching of health sciences has changed in the last century, specially at medical school [4]. In the first half of the twentieth century, the science-based curriculum was incorporated into traditional education, and in the second half of the same century it was added to problem-based teaching [2]. More recently, competency education has been introduced with the mission of providing global knowledge to healthcare professionals by providing knowledge, skills and attitudes associated with the acquisition of critical and ethical reasoning. In this way, teaching would fulfil its transforming role in society, changing from the informative to the formative model [5].

Several students, residents and trained doctors reported that they did not receive formal training in PC during their undergraduate and medical residency and do not feel qualified to attend terminally ill patients $[6,7]$. In 2013 , the Education Group of European Association for Palliative Care defined ten core competencies in PC [8,9]:

1. Applying the central constituents of palliative care in their own and safer environment for patients and families;

2. Increase physical comfort during the patient's illness trajectories;

3. Meet the psychological needs of patients;

4. Meet the social needs of the sick;

5. Address the spiritual needs of the sick;

6. Respond to the needs of family caregivers regarding the short, medium and long terms care goals;

7. Respond to the challenges of clinical and ethical decision making in palliative care; 
8. Implement comprehensive care coordination and interdisciplinary teamwork in all contexts where palliative care is offered;

9. Develop interpersonal and communication skills appropriate to palliative care;

10. Promote self-knowledge and continuous professional development.

PC are a part of medical education and it would be appropriate to identify which competencies were acquired and which could be improved during medical undergraduation. It was not identified in the literature an instrument that allowed the qualification of the acquisition of competencies during the medical graduation. Thus, the aim of this study was to develop and validate the Palliative Competency Tool (PalliComp) to qualify the acquisition of PC competencies among medical students.

\section{Method}

The study was conducted according to international research standards involving human subjects and was approved by the Ethics Committee in Brazil. All study participants were oriented and signed an informed consent form. The instrument was developed between January and February 2019, content validation between February and May 2019, the pilot study in June 2019 and the statistical study between August and October 2019.

\section{Instrument Development}

The study began with the construction of the PalliComp instrument that had the content based on the core competencies described by Gamondi et al. [8,9]. Only current scientific content was included and the objective was to develop an easy-to-understand instrument that would allow self-administration and time to complete less than 30 minutes.

Thirty-two questions were written (U.B.P.G.) that addressed all competencies. The questions were purposely written with correct and incorrect content and randomly distributed. Negative or double negative issues were avoided. The answers consisted of a five-point Likert scale (strongly agree, agree, do not agree or disagree, strongly disagree and disagree). The material was jointly reviewed by the researchers (U.B.P.G., C.C.P. and J.E.S.), revised and 30 questions remained.

\section{Content Validation}

The Delphi methodology was chosen for content validation, as it's an useful methodology for content establishment, systematically and structured to evaluate expert opinion, such as the content of an instrument [1013]. The Delphi methodology was limited to a minimum of two steps and a maximum of five steps.

The panel of experts were composed by university professors specialized in PC from all the country and they evaluate the instrument. The inclusion criteria of the specialists were: 1) being a brazilian native, 2) being a physician with PC training, 3) being nominated by the directors of the Academia Nacional de Cuidados Paliativos (society that aggregates PC in Brazil) and 4) being a university teacher for at least 1 year. The initial contact was by telephone and those who agreed to participate had up to twenty days to answer each validation step with weekly email reminders. If the expert did not participate in one step, he would be excluded from subsequent steps. Experts received the instrument in electronic format (SurveyMonkey Inc., USA) and evaluated it individually without interference from other participants. 
The experts evaluated each item of the instrument in terms of writing (1 to 3 points), content adequacy with the related competency ( 1 to 4 points) and intention to maintain the item ( 1 to 3 points). The experts evaluated individually and were also able to propose corrections, exclusion or suggestions. And each item would be disapproved if it received an average rating $<70$ and approved if the score $\geq 70$. For final approval, the instrument should be completed in less than 30 minutes and an average rating $\geq 70$.

The results of each of the step were anonymously evaluated by the researchers (U.B.P.G. and C.C.P.). The expert's contributions that both researchers agreed were incorporated into the instrument. The disagreements were evaluated thru the following criteria: 1) scientific adequacy and 2) best approach to the competency. The adjusted instrument was submitted again to a new step in which the experts evaluated the adjustments in the same scale than before. This process was repeated until the items were approved (score $\geq 70$ ). The last step consisted of evaluating the final version allowing only pass or fail. The final instrument had 24 items.

\section{Pilot Study}

After the construction of the instrument and content validation, a pre-pilot study was carried out in which three second-year medical students completed the questionnaire and pointed out all terms they did not understand. The terms were adjusted in agreement with the researchers (U.B.P.G. and C.R.P.) and the students, without changing the content of the tool. The data obtained at this stage could not be included in the pilot study.

In the pilot study, 80 medical students enrolled at fourth-year were invited to complete the instrument. Of these, 71 met the inclusion criteria (to be a native brazilian, to be over 18 and agreed to participate in the study). Each student had up to 30 minutes to individually complete the instrument without consulting other materials. The instruments obtained were corrected and each item received a score of +1 (totally correct), +0,5 (correct), 0 (neutral alternative), $-0,5$ (incorrect) and -1 (totally incorrect), allowing a score between +24 to -24 points. For qualification of academic performance, those who obtained score $<50$ were considered insufficient, $\geq 50$ e $<75$ sufficient and $\geq 75$ excellent.

\section{Statistical method}

Data from the content validation step and pilot study were extracted in Excel ${ }^{\circledR}$ spreadsheet with frequency, mean and percentage studies and submitted to statistical analysis by the R Statistical Software version 3.4.4 (R Core Team 2013). The significance level adopted was 0.05 .

Bartlett's test of sphericity was performed to assess whether the correlation was adequate and should show $p<0.05$ to proceed the analysis. Bartlett's test of sphericity tests the hypothesis that the correlation matrix is an identity matrix, which would indicate that the variables are related, and therefore, suitable for structure detection. Sampling adequacy was assessed using the Kaiser-Meyer-Olkin test which indicates whether the correlation patterns are relatively compact and sparsely dispersed. The Kaiser-Meyer-Olkin is a statistic test that indicates the proportion of variance in the variables that might be caused by underlying factors. Values close to 1.0 generally indicate that a factor analysis may be useful with the data and if the value is less than 0.50 , the results of the factor analysis probably won't be very useful. The internal consistency of the instrument was assessed using Cronbach's alpha coefficient, which estimates the reliability of the instrument and the correlation between responses. The alpha coefficient is considered adequate between 0.6 and 0.95 . Finally, factor analysis is a statistical method used to describe correlated variables in terms of a potentially lower number of unobserved variables called factors. In order to facilitated, can be used factor rotation and the factors were extracted according to the Kaiser criteria (or eigenvalue above 1) and confirmed by the Scree plot [14,17]. 


\section{Results}

\section{Content Validation}

We identified 33 specialists who met the inclusion criteria. Of these, accepted to participate 24 participated in the first stage (100\%), 22 in the second (91.7\%), 19 in the third (79.2\%) and 18 in the final evaluation (75.0\%). Of the specialists, $41.7 \%$ had a master's degree, $62.5 \%$ doctorate and $25.0 \%$ postdoctoral. The teaching experience time was $9.7 \pm 7.7$ years.

In the first step of the Delphi methodology, the instrument despite having received satisfactory evaluation, all experts disapproved due the excessive time required in filling and evaluation (over 1 hour). The instrument was fully adjusted, reduced to 24 items and therefore the notes of the first step could not be compared with the subsequent steps. Then was evaluated in the second and third steps contained 24 statements. Final approval was obtained in the fourth step (Table 1).

Table 1 - Palliative Competency Tool instrument assessment: expert content validation

\begin{tabular}{|c|c|c|c|c|c|c|c|c|c|}
\hline Item & $\begin{array}{l}\text { 1st step* } \\
(n=24)\end{array}$ & $\begin{array}{l}\text { 2nd step } \\
(n=22)\end{array}$ & $\begin{array}{l}\text { 3rd step } \\
(n=19)\end{array}$ & $\begin{array}{l}\text { 4th step } \\
(n=18)\end{array}$ & Item & $\begin{array}{l}\text { 1st step* } \\
(n=24)\end{array}$ & $\begin{array}{l}\text { 2nd step } \\
(n=22)\end{array}$ & $\begin{array}{l}\text { 3rd step } \\
(n=19)\end{array}$ & $\begin{array}{l}\text { 4th step } \\
(n=18)\end{array}$ \\
\hline Q 1 & - & 85,8 & 79,6 & approved & Q 13 & - & 97,9 & 95,7 & approved \\
\hline Q 2 & - & 75,4 & 93,6 & approved & Q 14 & - & 96,7 & 75,5 & approved \\
\hline Q 3 & - & 99,1 & 91,1 & approved & Q 15 & - & 72,2 & 74,1 & approved \\
\hline Q 4 & - & 99,1 & 95,9 & approved & Q 16 & - & 75,4 & 97,2 & approved \\
\hline Q 5 & - & 98,7 & 88,6 & approved & Q 17 & - & 64,2 & 98,8 & approved \\
\hline Q 6 & - & 75,7 & 98,1 & approved & Q 18 & - & 64,2 & 74,6 & approved \\
\hline Q 7 & - & 79,9 & 81,6 & approved & Q 19 & - & 98,0 & 97,9 & approved \\
\hline Q 8 & - & 75,2 & 74,8 & approved & Q 20 & - & 90,9 & 81,8 & approved \\
\hline Q 9 & - & 98,9 & 98,9 & approved & Q 21 & - & 95,6 & 74,0 & approved \\
\hline Q 10 & - & 79,4 & 77,9 & approved & Q 22 & - & 68,5 & 99,0 & approved \\
\hline Q 11 & - & 99,4 & 94,6 & approved & Q 23 & - & 96,7 & 71,8 & approved \\
\hline Q 12 & - & 86,7 & 74,4 & approved & Q 24 & - & 95,5 & 95,9 & approved \\
\hline
\end{tabular}

Note * disapproved for excessive evaluation time; $\mathrm{Q}=$ question

\section{Pilot Study}

The pre-pilot changed thee words and none statement. Seventh-one students agreed to participate in the pilot study. The average age was $23.4 \pm 2.6$ years, 30 (42.3\%) were men, 41 (57.7\%) women and only $17(23.9 \%)$ attended the elective PC course. Student answers and the score obtained for each item are described in Table 2 and Figure 1. 
Pilot sample scores were described as insufficient for 36 students (50.7\%), sufficient 26 (36.6\%) and excellent 9 $(12.7 \%)$. 
Table 2 - Answers from the students participating in the pilot study

\begin{tabular}{|c|c|c|c|c|c|c|c|c|c|}
\hline \multirow[t]{2}{*}{ Item } & \multirow{2}{*}{$\begin{array}{l}\text { Strongly } \\
\text { agree }\end{array}$} & \multirow[t]{2}{*}{ Agree } & \multirow{2}{*}{$\begin{array}{l}\text { Neither } \\
\text { agree } \\
\text { nor } \\
\text { disagree }\end{array}$} & \multirow[t]{2}{*}{ Disagree } & \multirow{2}{*}{$\begin{array}{l}\text { Strongly } \\
\text { disagree }\end{array}$} & \multicolumn{4}{|l|}{ Points } \\
\hline & & & & & & $\begin{array}{l}\text { Points } \\
(0- \\
100)\end{array}$ & $\begin{array}{l}\text { Insufficient } \\
(<50)\end{array}$ & $\begin{array}{l}\text { Sufficient } \\
\left({ }^{3} 50\right)\end{array}$ & $\begin{array}{l}\text { Excellent } \\
\left({ }^{3} 75\right)\end{array}$ \\
\hline \multirow[t]{2}{*}{ Q 1} & 30 & 33 & 2 & 5 & 0 & 72,5 & 8 & 33 & 30 \\
\hline & $(42,3 \%)$ & $(46,5 \%)$ & $(2,8 \%)$ & $(7,0 \%)$ & $(0 \%)$ & & $(11,3 \%)$ & $(46,5 \%)$ & $(42,3 \%)$ \\
\hline \multirow{2}{*}{$\begin{array}{l}Q \\
2 \#\end{array}$} & 4 & 6 & 12 & 30 & & 67,6 & & 0 & 61 \\
\hline & $(5,6 \%)$ & $(8,5 \%)$ & $(16,9 \%)$ & $(42,3 \%)$ & $(23,9 \%)$ & & $(14,1 \%)$ & $(0 \%)$ & $(85,9 \%)$ \\
\hline \multirow[t]{2}{*}{ Q 3} & 35 & 28 & 5 & 1 & 0 & 84,2 & 8 & 28 & 35 \\
\hline & $(49,3 \%)$ & $(39,4 \%)$ & $(7,0 \%)$ & $(1,4 \%)$ & $(0 \%)$ & & $(11,3 \%)$ & $(39,4 \%)$ & $(49,3 \%)$ \\
\hline \multirow[t]{2}{*}{ Q 4} & 39 & 25 & 6 & 0 & 0 & 86,3 & 7 & 0 & 64 \\
\hline & $(54,9 \%)$ & $(35,2 \%)$ & $(8,5 \%)$ & & $(0 \%)$ & & $(9,9 \%)$ & $(0 \%)$ & $(90,1 \%)$ \\
\hline \multirow[t]{2}{*}{ Q 5} & 43 & 23 & 3 & 0 & 1 & 87,7 & 1 & 0 & 70 \\
\hline & $(60,6 \%)$ & $(32,4 \%)$ & $(4,2 \%)$ & $(0 \%)$ & $(1,4 \%)$ & & $(1,4 \%)$ & $(0 \%)$ & $(98,6 \%)$ \\
\hline \multirow{2}{*}{$\begin{array}{l}Q \\
6 \#\end{array}$} & 4 & 6 & 4 & 30 & 26 & 73,9 & 10 & 0 & 61 \\
\hline & $(5,6 \%)$ & $(8,5 \%)$ & $(5,6 \%)$ & $(42,3 \%)$ & $(36,6 \%)$ & & $(14,1 \%)$ & $(0 \%)$ & $(85,9 \%)$ \\
\hline \multirow{2}{*}{$\begin{array}{l}\text { Q } \\
7 \#\end{array}$} & 5 & 8 & 12 & 33 & 11 & 63,0 & 13 & 0 & 58 \\
\hline & $(7,0 \%)$ & $(11,3 \%)$ & $(16,9 \%)$ & $(46,5 \%)$ & $(15,5 \%)$ & & $(18,3 \%)$ & $(0 \%)$ & $(81,7 \%)$ \\
\hline \multirow{2}{*}{$\begin{array}{l}\mathrm{Q} \\
8 \#\end{array}$} & 11 & 15 & 12 & 24 & 7 & 50,4 & 26 & 0 & 45 \\
\hline & $(15,5 \%)$ & $(21,1 \%)$ & $(16,9 \%)$ & $(33,8 \%)$ & $(9,9 \%)$ & & $(36,6 \%)$ & $(0 \%)$ & $(63,4 \%)$ \\
\hline \multirow[t]{2}{*}{ Q 9} & 32 & 29 & 7 & 2 & 0 & 82,0 & 10 & 29 & 32 \\
\hline & $(45,1 \%)$ & $(40,8 \%)$ & $(9,9 \%)$ & $(2,8 \%)$ & $(0 \%)$ & & $(14,1 \%)$ & $(40,8 \%)$ & $(45,1 \%)$ \\
\hline \multirow{2}{*}{$\begin{array}{l}\mathrm{Q} \\
10\end{array}$} & 33 & 27 & 8 & 2 & 0 & 82,0 & 11 & 27 & 33 \\
\hline & $(46,5 \%)$ & $(38,0 \%)$ & $(11,3 \%)$ & $(2,8 \%)$ & $(0 \%)$ & & $(15,5 \%)$ & $(38,0 \%)$ & $(46,5 \%)$ \\
\hline \multirow{2}{*}{$\begin{array}{l}\mathrm{Q} \\
11\end{array}$} & 37 & 26 & 6 & 1 & 0 & 84,9 & 8 & 26 & 37 \\
\hline & $(52,1 \%)$ & $(36,6 \%)$ & $(8,5 \%)$ & $(1,4 \%)$ & $(0 \%)$ & & $(11,3 \%)$ & $(36,6 \%)$ & $(52,1 \%)$ \\
\hline \multirow{2}{*}{$\begin{array}{l}\mathrm{Q} \\
12 \#\end{array}$} & 7 & 22 & 16 & 21 & 4 & 47,5 & 29 & 0 & 42 \\
\hline & $(9,9 \%)$ & $(31,0 \%)$ & $(22,5 \%)$ & $(29,6 \%)$ & $(5,6 \%)$ & & $(40,8 \%)$ & $(0 \%)$ & $(59,2 \%)$ \\
\hline \multirow{2}{*}{$\begin{array}{l}\mathrm{Q} \\
13\end{array}$} & 44 & 23 & 2 & 0 & 0 & 89,1 & 4 & 0 & 67 \\
\hline & $(62,0 \%)$ & $(32,4 \%)$ & $(2,8 \%)$ & $(0 \%)$ & $(0 \%)$ & & $(5,6 \%)$ & $(0 \%)$ & $(94,4 \%)$ \\
\hline \multirow{2}{*}{$\begin{array}{l}Q \\
14\end{array}$} & 42 & 27 & 0 & 0 & 0 & 89,1 & 2 & 0 & 69 \\
\hline & $(59,2 \%)$ & $(38,0 \%)$ & $(0 \%)$ & $(0 \%)$ & $(0 \%)$ & & $(2,8 \%)$ & $(0 \%)$ & $(97,2 \%)$ \\
\hline
\end{tabular}




\begin{tabular}{|c|c|c|c|c|c|c|c|c|c|}
\hline $\begin{array}{l}Q \\
15 \#\end{array}$ & $\begin{array}{l}4 \\
(5,6 \%)\end{array}$ & $\begin{array}{l}15 \\
(21,1 \%)\end{array}$ & $\begin{array}{l}20 \\
(28,2 \%)\end{array}$ & $\begin{array}{l}26 \\
(36,3 \%)\end{array}$ & $\begin{array}{l}5 \\
(7,0 \%)\end{array}$ & 54,2 & $\begin{array}{l}20 \\
(28,2 \%)\end{array}$ & $\begin{array}{l}0 \\
(0 \%)\end{array}$ & $\begin{array}{l}51 \\
(71,8 \%)\end{array}$ \\
\hline $\begin{array}{l}Q \\
16 \#\end{array}$ & $\begin{array}{l}1 \\
(1,4 \%)\end{array}$ & $\begin{array}{l}3 \\
(4,2 \%)\end{array}$ & $\begin{array}{l}8 \\
(11,3 \%)\end{array}$ & $\begin{array}{l}32 \\
(45,1 \%)\end{array}$ & $\begin{array}{l}26 \\
(36,6 \%)\end{array}$ & 78,2 & $\begin{array}{l}4 \\
(5,6 \%)\end{array}$ & $\begin{array}{l}0 \\
(0 \%)\end{array}$ & $\begin{array}{l}67 \\
(94,4 \%)\end{array}$ \\
\hline $\begin{array}{l}Q \\
17\end{array}$ & $\begin{array}{l}33 \\
(46,5 \%)\end{array}$ & $\begin{array}{l}32 \\
(45,1 \%)\end{array}$ & $\begin{array}{l}4 \\
(5,6 \%)\end{array}$ & $\begin{array}{l}1 \\
(1,4 \%)\end{array}$ & $\begin{array}{l}0 \\
(0 \%)\end{array}$ & 84,9 & $\begin{array}{l}5 \\
(7,0 \%)\end{array}$ & $\begin{array}{l}32 \\
45,1 \%\end{array}$ & $\begin{array}{l}34 \\
(47,9 \%)\end{array}$ \\
\hline $\begin{array}{l}Q \\
18 \#\end{array}$ & $\begin{array}{l}9 \\
(12,7 \%)\end{array}$ & $\begin{array}{l}23 \\
(32,4 \%)\end{array}$ & $\begin{array}{l}16 \\
(22,5 \%)\end{array}$ & $\begin{array}{l}14 \\
(19,7 \%)\end{array}$ & $\begin{array}{l}8 \\
(11,3 \%)\end{array}$ & 45,8 & $\begin{array}{l}33 \\
(46,5 \%)\end{array}$ & $\begin{array}{l}0 \\
(0 \%)\end{array}$ & $\begin{array}{l}48 \\
(53,5 \%)\end{array}$ \\
\hline $\begin{array}{l}\text { Q } \\
19\end{array}$ & $\begin{array}{l}22 \\
(31,0 \%)\end{array}$ & $\begin{array}{l}20 \\
(28,2 \%)\end{array}$ & $\begin{array}{l}18 \\
(25,4 \%)\end{array}$ & $\begin{array}{l}9 \\
(12,7 \%)\end{array}$ & $\begin{array}{l}1 \\
(1,4 \%)\end{array}$ & 69,4 & $\begin{array}{l}10 \\
(14,1 \%)\end{array}$ & $\begin{array}{l}0 \\
(0 \%)\end{array}$ & $\begin{array}{l}61 \\
(85,9 \%)\end{array}$ \\
\hline $\begin{array}{l}\mathrm{Q} \\
20\end{array}$ & $\begin{array}{l}24 \\
(33,8 \%)\end{array}$ & $\begin{array}{l}24 \\
(33,8 \%)\end{array}$ & $\begin{array}{l}12 \\
(16,9 \%)\end{array}$ & $\begin{array}{l}5 \\
(7,0 \%)\end{array}$ & $\begin{array}{l}3 \\
(4,2 \%)\end{array}$ & 72,2 & $\begin{array}{l}8 \\
(11,3 \%)\end{array}$ & $\begin{array}{l}0 \\
(0 \%)\end{array}$ & $\begin{array}{l}63 \\
(88,7 \%)\end{array}$ \\
\hline $\begin{array}{l}Q \\
21\end{array}$ & $\begin{array}{l}41 \\
(57,7 \%)\end{array}$ & $\begin{array}{l}24 \\
(33,8 \%)\end{array}$ & $\begin{array}{l}2 \\
(2,8 \%)\end{array}$ & $\begin{array}{l}0 \\
(0 \%)\end{array}$ & $\begin{array}{l}0 \\
(0 \%)\end{array}$ & 88,0 & $\begin{array}{l}5 \\
(7,0 \%)\end{array}$ & $\begin{array}{l}0 \\
(0 \%)\end{array}$ & $\begin{array}{l}66 \\
(93,0 \%)\end{array}$ \\
\hline $\begin{array}{l}\mathrm{Q} \\
22 \#\end{array}$ & $\begin{array}{l}3 \\
(4,2 \%)\end{array}$ & $\begin{array}{l}9 \\
(12,7 \%)\end{array}$ & $\begin{array}{l}31 \\
(43,7 \%)\end{array}$ & $\begin{array}{l}25 \\
(35,2 \%)\end{array}$ & $\begin{array}{l}1 \\
(1,4 \%)\end{array}$ & 54,2 & $\begin{array}{l}12 \\
(16,9 \%)\end{array}$ & $\begin{array}{l}0 \\
(0 \%)\end{array}$ & $\begin{array}{l}59 \\
(83,1 \%)\end{array}$ \\
\hline $\begin{array}{l}Q \\
23\end{array}$ & $\begin{array}{l}19 \\
(26,8 \%)\end{array}$ & $\begin{array}{l}34 \\
(47,9 \%)\end{array}$ & $\begin{array}{l}13 \\
(18,3 \%)\end{array}$ & $\begin{array}{l}3 \\
(4,2 \%)\end{array}$ & $\begin{array}{l}0 \\
(0 \%)\end{array}$ & 74,6 & $\begin{array}{l}17 \\
(23,9 \%)\end{array}$ & $\begin{array}{l}35 \\
(49,3 \%)\end{array}$ & $\begin{array}{l}19 \\
(26,8 \%)\end{array}$ \\
\hline $\begin{array}{l}Q \\
24\end{array}$ & $\begin{array}{l}42 \\
(59,2 \%)\end{array}$ & $\begin{array}{l}25 \\
(35,2 \%)\end{array}$ & $\begin{array}{l}1 \\
(1,4 \%)\end{array}$ & $\begin{array}{l}11 \\
(1,4 \%)\end{array}$ & $\begin{array}{l}1 \\
(1,4 \%)\end{array}$ & 87,7 & $\begin{array}{l}2 \\
(2,8 \%)\end{array}$ & $\begin{array}{l}0 \\
(0 \%)\end{array}$ & $\begin{array}{l}69 \\
(97,2 \%)\end{array}$ \\
\hline
\end{tabular}

Note: \# Question with purposely incorrect construction; Q = question

\section{Approach to Statistical Analysis and Validation}

The missing data were excluded. Statistical analysis of the sample showed an adequate identity matrix, with Bartlett's test sphericity $p<0.001$. The Kaiser-Meyer-Olkin test $=0.7$, which indicates that the data were relatively compact and factorial analysis was recommended. The better rotation founded was promax rotation and it indicates eight factors extraction. The internal consistency of the instrument revealed Cronbach's alpha index of 0.7 (Figure 2).

\section{Discussion}

Knowledge in PC is essential for the doctor, because the general practitioner will take care of patients facing terminality in the daily practice. Several recommendations have already been made with the intention of standardizing PC teaching in undergraduate courses $[8,9,18-23]$. In general, all of them recommend an approach to pain management and other uncomfortable symptoms, a psychosocial and spiritual approach, bioethics, 
communication and teamwork. It is known that teaching activities should present theoretical and practical content in an integrated manner throughout the entire undergraduate course, with a focus on basic actions [3]. EAPC was innovative and proposed teaching through competencies $[8,9]$.

It is necessary to assess the learning of PC in medical graduation. One way of doing this would be to assess the acquisition of competencies throughout the training, so that learning could be measured and qualified. The authors found that there was no instrument to measure the acquisition of PC competencies among medical students. In this way, an effort was devoted to building and validating the Palliative Competency Tool in this version 1 , which has the characteristic of being self-applicable and requiring less than 30 minutes to be completed.

Building and validating the research instrument was a challenging experience. The inserted content should be based on consistent scientific literature and demanded research time from the authors. However, the competencies required for basic palliative care are broad and numerous, and the degree of depth of the approach in medical training has rarely been described in the literature [24,25].

It was decided to approach the competencies in the most direct way possible, avoiding hindering students' understanding. As the student answered the degree of agreement with each item, allowing a neutral response, the authors believe that the items that may have generated doubts had a response tending to neutral. It is known that the competencies used in this research have been described for several professions, including medicine [8,9], and in this way, some competencies had greater depth than others [26]. The researchers were careful to take these characteristics into the development, as well as the experts in the content validation were oriented to this fact.

The process of constructing the tool was a quite challenging, since the intention was that a set of statements would represent a competence, without interfering with the others and, at the same time, have the discriminative power, that is, the ability to assess whether the student showed whether or not knowledge, avoiding random success (because it is very easy) or error (very difficult) and, even, that it had appropriate language for the student. The content validation step with the specialists was essential to make the instrument suitable for what was proposed and the Delphi methodology, which is one technique that consists of the evaluation of a material by specialists, proved to be adequate for the proposed objective [10-13].

In order to Delphi methodology allow better results, the experts' choice was judicious, as their opinion guided the instrument. The experts' experience was defined by their degree and working time, as both knowledge in PC, clinical experience and teaching were fundamental. It was interesting to note that in the second stage, most items were already approved. As there was a need to follow the rules previously established, another step occurred, with the incorporation of corrections, which curiously reduced the score of isolated items, without compromising the final approval in the third step. The inclusion of the experts' suggestions, which had proven scientific suitability, is subject to personal perception.

The sample of students was chosen due to the feasibility and the need for a heterogeneous sample for validation. At the time of data collection, students were at the end of the academic semester and less than $25 \%$ studied PC, resulting in four competencies with insufficient performance, demonstrating that the acquisition of competencies could still improve. The purpose of this description was to build and validate the instrument and, therefore, this discussion is not part of the material and may not reflect the course as a whole.

The study of the instrument's internal reliability and consistency was assessed using Cronbach's alpha index, and it was considered adequate between 0.6 and $0.95 . .^{14-16}$ The correlation found in this study $(=0.7)$ may be better with 
the application in a larger population, as in the entire medical course. However, massive application would only be justified if we had confirmation of the validation of the questionnaire. The statistical validation of the research tool was satisfactory.

The competencies described by the EAPC [8,9] are broad and sometimes overlaping. Such overlap may have hindered the validation, since the competencies are mixed in the writing of the questionnaire items. A review will be valid; however, it is assumed that it is almost impossible to isolate each competence in just one item and would be inconsistent with the assistance reality.

It should be remembered that competency education was defined by the process of acquiring knowledge, skills and attitudes that belong to a specific professional area. ${ }^{2}$ In this context, teachers are concerned with how to teach competencies, correct and evaluate this acquisition. Measuring the acquisition of competencies is challenging, but a necessary effort to improve medical education. From this instrument, the process of acquiring competencies can be evaluated and better targeted.

The PC education in Brazil are still insufficient. Out of 300 registered courses, only 14 offer them regularly [27]. In Europe, of the 53 countries recognized, $65 \%$ teach PC in medical school, and $30 \%$ in all schools as a compulsory subject [28]. However, Centeno and Rodrigues Núñez [29] reported the weakness of studies in medical education and affirmed the need to better structure education to promote medical but favourable attitudes towards end-of-life care. In the United States, PC education has been taking place for over fourth years, with variation among medical schools and it is estimated that over $90 \%$ of students were affected by the content $[24,30]$.

This study has limitations. In order to study the process of acquiring competencies, it is necessary to expand the sample and include all students of the course and also apply the instrument prospectively. The authors have already started the prospective study in two years and we will have more answers. The study was entirely carried out in Brazil and the choice was due to the feasibility of the research, but it can bring cultural limitations. In the future, it will be interesting to validate and adapt culturally in other contexts. The intention was to create a toll that would allow to qualify PC teaching and compare it over time. Therefore, it can be said that the data obtained can be treated as a "diagnosis" of PC teaching [5] and should not be interpreted individually or for the purpose of classificatory assessment.

\section{Conclusion}

With the data described in this study, it can be concluded that it was possible to construct and validate Palliative Competency Tool (PalliComp), an instrument of qualification of competencies acquisition of PC. Will be appropriate to proceed with the evaluation of all students of a medical course, to evaluate the acquisition during undergraduation and possibly to expand to other medical schools.

\section{Declarations}

\section{ACKNOWLEDGEMENTS}

To all the teachers and students who participated in the validation steps of this instrument, to Luis Otavio Zatore and Gustavo Belam Fioravanti for processing the data in a spreadsheet and to Pedro Ivan Klassen and Ricardo Rasmussen Petterle for statistical analysis. 
DISCLOSURE STATEMENT

None of the authors has any conflict of interest to declare.

FUNDING

No funding were obtained for this study.

AUTHOR INFORMATION

Affiliations

Universidade Federal do Paraná, Curitiba, Brazil (corresponding author)

Ursula Bueno do Prado Guirro

Pontifícia Universidade Católica do Paraná, Curitiba, Brazil

Carla Corradi Perini and José Eduardo de Siqueira

Contributions

UBPG: conception, data analysis, writing, revising and manuscript approval. CCP and JES: conception, data analysis, revising and manuscript approval. All the authors have read the manuscript and agree in its submission to BMC Medical Education and consent it is done.

\section{ETHICS DECLARATIONS}

All participants were consent to participate.

This study had an ethics committee approval by the "Comitê de Ética em Pesquisas com Seres Humanos da Universidade Federal do Paraná", registered by CAAE 99340218.0.0000.0102.

Consent for publication

All data were obtained after written informed consent to answer and for data to be analysed and published.

Competing interests

The authors declare that they have no competing interests.

\section{References}

1. World Health Organization. 2020. WHO Definition of Palliative Care. [accessed 2020 Mar 11]. https://www.who.int/cancer/palliative/definition/en/

2. Perrenoud P, Thurler MG, Macedo L, Machado NJ, Allessandrini CD. As competências para ensinar no século XXI: a formação de professores e o desafio da avaliação. Porto Alegre: Penso Editora; 2002.

3. Boland JW, Barclay S, Gibbins J. Twelve tips for developing palliative care teaching in an undergraduate curriculum for medical students. Med Teach. 2019;41(12):1359-1365. 
4. Frenk J, et al. Health professionals for a new century: transforming education to strengthen health systems in an interdependent world. Lancet. 2010;376:1923-58.

5. Scallon G. Avaliação da aprendizagem numa abordagem por competências. Curitiba: PUCPRess; 2015.

6. Fitzpatrick D, Heah R, Patten S, Ward H. Palliative Care in Undergraduate Medical Education-How Far Have We Come? Am J Hosp Palliat Care. 2017;34(8):762-73.

7. Walker S, Gibbins J, Paes P, Adams A, Chandratilake M, Gishen F, Lodge P, Wee B, Barclay S. Palliative care education for medical students: Differences in course evolution, organisation, evaluation and funding: a survey of all UK medical schools. Palliat Med. 2017;31(6):575-81.

8. Gamondi C, Larkin P, Payne S. Core competencies in palliative care: an EAPC white paper on palliative care education: part 1. Eur J Pall Care. 2013;20(2):86-91.

9. Gamondi C, Larkin P, Payne S. Core competencies in palliative care: an EAPC white paper on palliative care education: part 2. Eur J Pall Care. 2013;20(3):140-5.

10. Hasson F, Keeney S, McKenna H. Research guidelines for Delphi survey technique. J Adv Nurs. 2000;32:100815.

11. Boulkedid R, Abdoul H, Loustau M, Sibony O, Alberti C. Using and reporting the Delphi method for selecting healthcare quality indicators: a systematic review. PLoS One. 2011;6(6):e20476.

12. Humphrey-Murto S, Varpio L, Wood TJ, Gonsalves C, Ufholz LA, Mascioli K, Wang C, Foth T. The Use of the Delphi and Other Consensus Group Methods in Medical Education Research: A Review. Acad Med. 2017;92(10):1491-8.

13. Marques JBV, Freitas D. The DELPHI method: characterization and potentialities for educational research. ProPosições. 2018;29(2):389-415.

14. Hora HRM, Monteiro GTR, Arica J. Confiabilidade em Questionários para Qualidade: Um Estudo com o Coeficiente Alfa de Cronbach. Produto \& Produção. 2010;11(2): 85-103.

15. Norman G. Likert scales, levels of measurement and the "laws" of statistics. Adv Health Sci Educ Theory Pract. 2010;15(5):625-32.

16. Ventura-León JL. Is this the end for Cronbach's alpha? Adicciones. 2019;31(1):80-81.

17. Nobre EB. Construction and validation of a questionnaire to describe the life style of preschoolers' mothers [master's thesis]. São Paulo (SP): Universidade de São Paulo; 2012.

18. Competencies Project Work Group (USA). Hospice and Palliative Medicine Core Competencies version 2.3. Chicago (IL): American Academy Hospice and Palliative Medicine; 2009. [accessed 2020 April 1] http://aahpm.org/uploads/education/competencies/Competencies\%20v.\%202.3.pdf

19. Bruera E, Billings JA, Lupu D, Ritchie CS, Academic Palliative Medicine Task Force of the American Academy of Hospice and Palliative Medicine. AAHPM Position Paper: Requirements for the Successful Development of Academic Palliative Care Programs. J Pain and Symptom Manage. 2010;39(4):743-55.

20. Ryan K, et al. Palliative Care Competence Framework Steering Group. (2014). Palliative Care Competence Framework. Dublin (Ireland): Health Service Executive; 2014. [accessed 2020 April 14] https://www.hse.ie/eng/services/publications/clinical-strategy-and-programmes/palliative-care-frameworkdocument.pdf

21. Pastrana T, et al. Palliative care competencies in undergraduate education [Competencias en Cuidados Paliativos en Educación de Pregrado]. Houston (USA): International Association for Hospice and Palliative Care; 
2015. [accessed 2020 April 14] http://paliativoscolombia.org/wp-content/uploads/2014/12/Competencias-enCP-en-Educaci\%C3\%83\%C2\%B3n-de-Pregrado-Final.pdf

22. McCallum M, Carver J, Dupere D, Ganong S, Henderson D, McKim A, McNeil-Campbell L, Richardson H, Simpson J, Tschupruk C, Jewers H. Developing a Palliative Care Competency Framework for Health Professionals and Volunteers: The Nova Scotian Experience. J Palliat Med. 2018;21(7):947-55.

23. BC Centre for Palliative Care. BC Centre for Palliative Care: Inter-professional palliative competency framework. New Westminster (Canada): BC Centre for Palliative; 2019. [accessed 2020 April 14] https://bc-cpc.ca/cpc/wpcontent/uploads/2019/09/Competency_Framework_May2019.pdf

24. Horowitz R, Gramling R, Quill T. Palliative care education in U.S. medical schools. Med Educ. 2014;48(1):59-66.

25. Caldas GHO, Moreira SNT, Vilar MJ. Palliative care: a proposal for undergraduate education in medicine. Rev Bras Geriatr Gerontol. 2018;21(3):269-80.

26. Harris JA, Herrel LA, Healy MA, Wancata LM, Perumalswami CR. Milestones for the Final Mile: Interspecialty Distinctions in Primary Palliative Care Skills Training. Journal of Pain and Symptom Management. 2016;52(3):345-52.e5.

27. Academia Nacional de Cuidados Paliativos. Academia Nacional de Cuidados Paliativos. [acessed 2020 Mar 11] https://paliativo.org.br/comites/

28. Carrasco JM, Lynch TJ, Garralda E, Woitha K, Elsner F, Filbet M, Ellershaw JE, Clark D, Centeno C. Palliative Care Medical Education in European Universities: A Descriptive Study and Numerical Scoring System Proposal for Assessing Educational Development. J Pain Symptom Manage. 2015;50(4):516-23.e2.

29. Centeno C, Núñez R. The contribution on undergraduate palliative care education: does it influence the clinical patient's care? Curr Opin Support Palliat Care. 2015;9(4):375-91.

30. Dickinson GE. A 40-Year History of End-of-Life Offerings in US Medical Schools: 1975-2015. Am J Hosp Palliat Care. 2017;34(6):559-565.

\section{Figures}

100

80

60

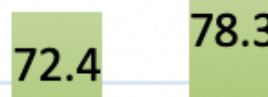

40

20

0

\section{3}

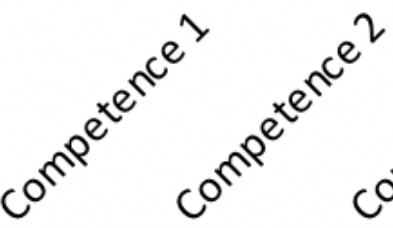

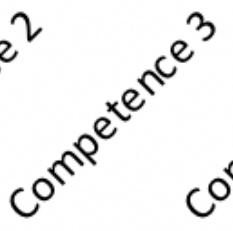
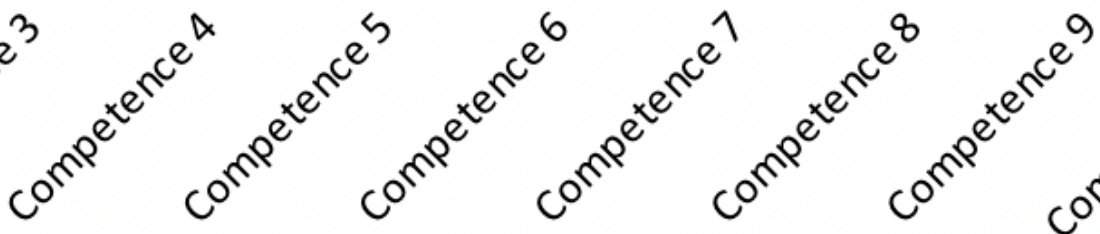

68.3

61.5

65.8

81.5

75.4

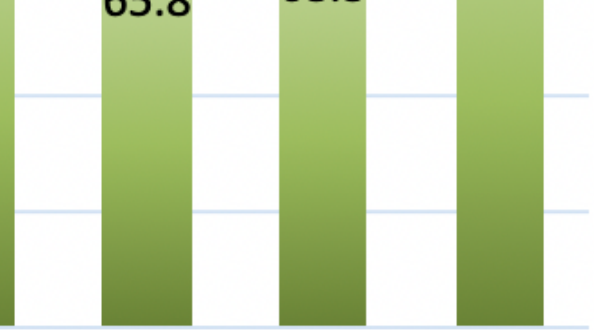

Page 13/14 
Figure 1

Mean scores obtained by students participating in the pilot study

Scree plot

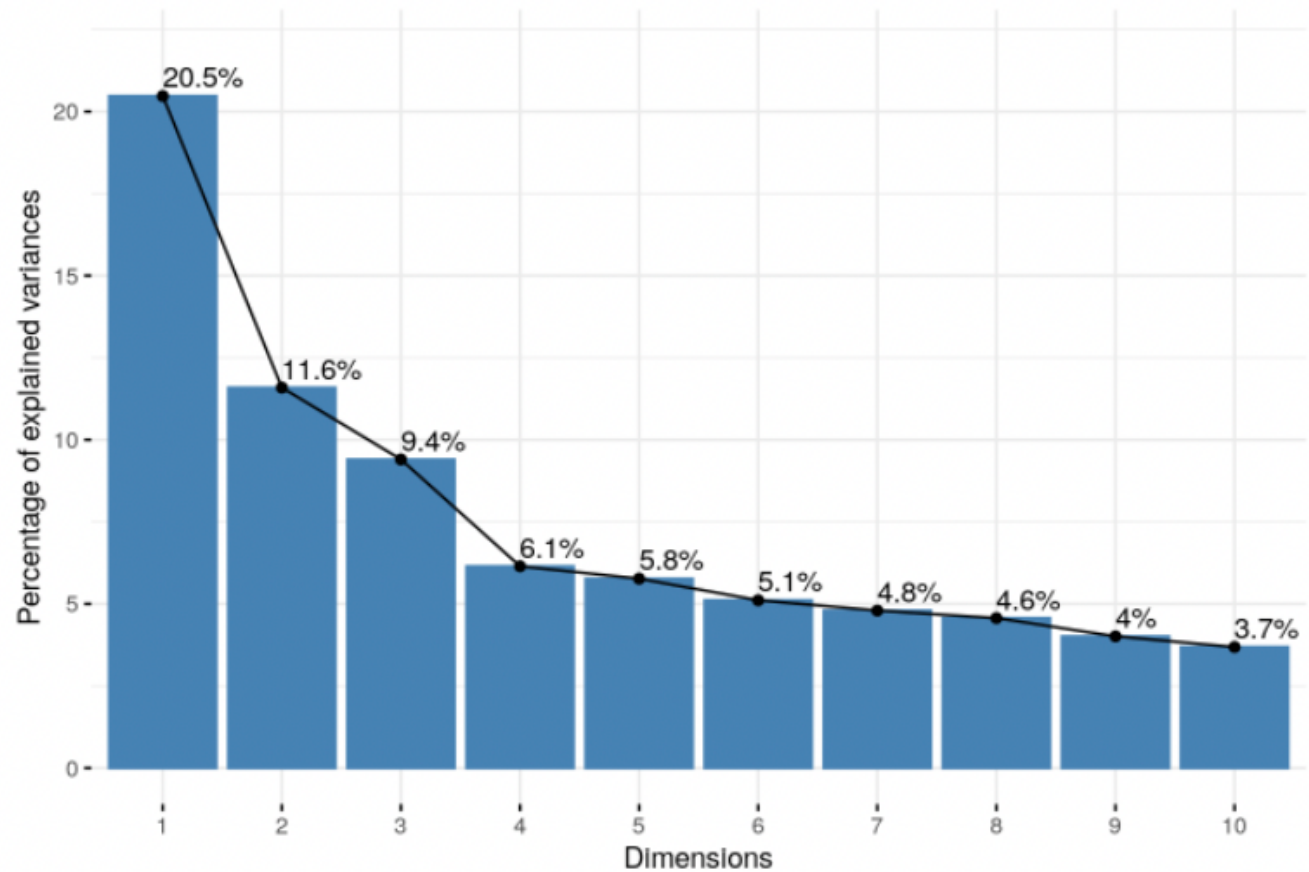

\section{Factor Analysis*}

\begin{tabular}{c|c|c|c|c|c|c|c|c|c}
\hline Factor & Factor 1 & Factor 2 & Factor 3 & Factor 4 & Factor 5 & Factor 6 & Factor 7 & Factor 8 & Exclusion \\
\hline Question & $\begin{array}{c}\text { Q3, Q4, } \\
\text { Q13, } \\
\text { Q13, } \\
\text { Q14 }\end{array}$ & $\begin{array}{c}\text { Q12, } \\
\text { Q15, } \\
\text { Q18, } \\
\text { Q22 }\end{array}$ & $\begin{array}{c}\text { Q11, } \\
\text { Q17 }\end{array}$ & Q21 & $\begin{array}{c}\text { Q2, Q19, } \\
\text { Q20 }\end{array}$ & Q16 & Q7 & Q1, Q5 & Q23, Q24 \\
\hline $\begin{array}{c}\text { Proportion } \\
\text { Variavel }\end{array}$ & 0.13 & 0.09 & 0.07 & 0.06 & 0.06 & 0.05 & 0.05 & 0.04 & - \\
\hline $\begin{array}{c}\text { Cumulative } \\
\text { Variavel }\end{array}$ & 0.13 & 0.21 & 0.28 & 0.34 & 0.40 & 0.45 & 0.50 & 0.55 & - \\
\hline
\end{tabular}

*Kaiser-Meyer-Olkin test: 0.7; Bartlett's Test of Sphericity: 0.001; Cronbach's alpha index of 0.7

Figure 2

Principal Component Analysis for Factor Extraction 